\title{
Ingestive behavior and thermoregulation in sheep fed forage cactus silage undergoing intermittent water supply
}

\section{Comportamento ingestivo e termorregulação em ovinos alimentados com silagem de palma forrageira submetidos a oferta intermitente de água}

\author{
Ismael de Sousa Nobre ${ }^{*}$; Gherman Garcia Leal de Araújoº $;$ Edson Mauro Santos ${ }^{3}$; \\ Gleidson Giordano Pinto de Carvalho ${ }^{4}$; Bonifácio Benicio de Souza ${ }^{5}$; Ossival \\ Lolato Ribeiro ${ }^{4}$; Silvia Helena Nogueira Turco ${ }^{6}$; Anderson Barbosa Cavalcante ${ }^{7}$; \\ Italo Reneu Rosas de Albuquerque ${ }^{8}$
}

\begin{abstract}
This study aimed to assess the effect of using forage cactus silage in the diet of sheep under intermittent water supply on its ingestive behavior and thermoregulation. We used in the experiment thirty-six intact male sheep of undefined genotype with an initial average weight of $19.8 \pm 2.1 \mathrm{~kg}$ and age of approximately six months. The experimental design was a randomized block design in a $3 \times 3$ factorial scheme composed of three levels of forage cactus silage in the diet $(0,21$, and $42 \%)$, three water supply periods $(0,24$, and 48 hours), and four replications. For the ingestive behavior, observations were carried out every 5 minutes for 2 periods of 24 hours. Thermoregulatory responses were taken at 7:00 and 15:00 $\mathrm{h}$ on days other than those intended for ingestive behavior tests. Intermittent water supply did not affect any of the studied variables $(\mathrm{P}>0.05)$. The use of forage cactus silage significantly influenced the ingestive behavior of animals $(\mathrm{P}<0.05)$. Sheep fed forage cactus silage in the diet presented an average feeding efficiency of $255.77 \mathrm{~g} \mathrm{DM} \mathrm{h}^{-1}$ and an average rumination efficiency of $102.16 \mathrm{~g} \mathrm{DM} \mathrm{h}^{-1}$, while animals fed control diet showed values of 198.63 and $78.45 \mathrm{~g} \mathrm{DM} \mathrm{h}^{-1}$, respectively. Urinary frequency increased according to the levels of forage cactus silage in the diet, with 23.60 urination per day in animals fed diets with $42 \%$ of forage cactus silage and 10.83 urination per day in animals fed control diet. However, the search for water reduced, with averages of 2.73 and 0.54 per day for animals fed 0 and $42 \%$ forage cactus silage, respectively. The use of forage cactus silage also increased thermoregulatory responses of sheep, with an average respiratory rate of $103.35 \mathrm{mov} . \mathrm{min}^{-1}$ and heart rate of $140.08 \mathrm{mov}$.
\end{abstract}

1 Discente, Curso de Doutorado, Programa de Pós-Graduação em Zootecnia, Universidade Federal da Paraíba, UFPB, Areia, PB, Brasil. E-mail: ismaelzootec@hotmail.com

2 Prof. Dr., Empresa Brasileira de Pesquisa Agropecuária, EMBRAPA Semiárido, Petrolina, PE, Brasil. E-mail: gherman.araujo@ embrapa.br

3 Prof. Dr., Programa de Pós-Graduação em Zootecnia, UFPB, Areia, PB, Brasil. E-mail: edson@cca.ufpb.br

4 Profs. Drs., Programa de Pós-Graduação em Zootecnia, Universidade Federal da Bahia, UFBA, Salvador, BA, Brasil. E-mail: gleidsongiordano@ufba.br; ossribeiro@yahoo.com.br

5 Prof. Dr., Programa de Pós-Graduação em Zootecnia, Universidade Federal de Campina Grande, UFCG, Patos, PB, Brasil. E-mail: bonif@ufcg.cstr.edu.br

6 Prof $^{a}$ Dr $^{\mathrm{a}}$, Programa de Pós-Graduação em Engenharia Agrícola, Universidade Federal do Vale do São Francisco, UNIVASF, Juazeiro, BA, Brasil. E-mail: silvia.turco@univasf.edu.br

7 Discente, Curso de Mestrado, Programa de Pós-Graduação em Ciência Animal, UNIVASF, Petrolina, PE, Brasil. E-mail: andersonbarcante@outlook.com

8 Discente, Curso de Doutorado, Programa de Pós-Graduação em Ciência Animal nos Trópicos, UFBA, Salvador, BA, Brasil. E-mail: italoreneu@hotmail.com

* Author for correspondence 
$\min ^{-1}$ in the warmest period of the day (in the afternoon). Thus, sheep fed forage cactus silage increases its feeding and rumination efficiencies, decreases its search for water, and increases its thermoregulatory responses. The intermittent water supply within 48 hours does not influence the ingestive behavior and thermoregulation of confined sheep.

Key words: Animal welfare. Physiological parameters. Thermoregulatory responses. Rumination.

\section{Resumo}

Objetivou-se avaliar o efeito da utilização de silagem de palma forrageira na dieta de ovinos submetidos a oferta intermitente de água sobre o comportamento ingestivo e a termorregulação de ovinos. Foram utilizados 36 ovinos machos não castrados sem padrão racial, com peso médio inicial de 19,8 $+2,1 \mathrm{~kg}$ e idade aproximada de seis meses, distribuídos em delineamento de blocos ao acaso, em esquema fatorial $3 \times 3$, composto por três proporções de silagem de palma na dieta $(0 ; 21$ e $42 \%)$ e três períodos de oferta de água ( $0 ; 24$ e 48 horas), com quatro repetições. Para o comportamento ingestivo foram realizadas observações a cada 5 minutos durante 2 períodos de 24 horas. As respostas termorregulatórias foram tomadas nos horários das 7 e 15 horas, em dias diferentes daqueles destinados ao comportamento. Observou-se que a oferta intermitente de água não afetou nenhuma das variáveis estudadas $(\mathrm{P}>0,05)$. A utilização de silagem de palma influenciou significativamente o comportamento ingestivo dos animais $(\mathrm{P}<0,05)$. Ovinos alimentados com silagem de palma forrageira na dieta apresentaram eficiência de alimentação média de $255,77 \mathrm{gMS} \mathrm{h}^{-1}$ e de ruminação de $102,16 \mathrm{gMS} \mathrm{h}^{-1}$, enquanto que aqueles que não recebiam esse alimento, apresentaram valores dessas variáveis de 198,63 e 78,45 $\mathrm{gMS} \mathrm{h}^{-1}$, respectivamente. A frequência urinária dos animais se elevou conforme a proporção de silagem de palma na dieta, sendo observadas 23,60 micções dia $^{-1}$ em animais que recebiam 42\% e 10,83 micções dia $^{-1}$ naqueles que não recebiam silagem de palma. A procura por água, entretanto, diminuiu. Foram observadas médias de 2,73 e 0,54 ( $\left.\mathrm{n}^{\mathrm{o}} \mathrm{dia}^{-1}\right)$ para animais alimentados com 0 e $42 \%$ de silagem de palma, respectivamente. A utilização da silagem de palma também elevou as respostas termorregulatórias dos ovinos. Ovinos alimentados com silagem de palma apresentaram média de frequência respiratória de 103,35 e cardíaca de 140,08 movimentos minuto $^{-1}$ no período mais quente do dia (tarde). Concluiuse que a silagem de palma na dieta aumenta as eficiências de alimentação e ruminação, além de diminuir a procura por água em ovinos em confinamento. No entanto, também eleva suas respostas termorregulatórias. A oferta intermitente de água em até 48 horas não influencia o comportamento ingestivo e a termorregulação de ovinos em confinamento.

Palavras-chave: Bem estar animal. Parâmetros fisiológicos. Respostas termorregulatórias. Ruminação.

\section{Introduction}

The northeastern semi-arid region of Brazil is characterized by long periods of drought. During these periods, there is usually a shortage of food and water for animals. Abdelatif et al. (2010) stated that the low availability of food and drinking water are limiting factors for animals reared in this region and that the persistence of prolonged periods of drought causes the animals to walk long distances away from water points. However, even when walking long distances, these animals are faced with food of low nutritional value and water scarcity. Thus, these animals have developed mechanisms of physiological, morphological, and behavioral adaptation that allow them to survive and tolerate dehydration (AL-RAMAMNEH et al., 2011).

Given the demand for potable water by the population living in arid and semi-arid regions and the low precipitation associated with a high evaporation in the recurrent periods of drought that affect these regions, many researchers (ADOGLABESSA; AGANGA, 2000; CASAMASSIMA et al., 2008; ALAMER, 2009; SILVA et al., 2016) have sought water supply strategies that increase the efficiency in the use of this essential and limited element for animal production. 
Water in food is an important source of this element for animals, especially for animals reared in semi-arid regions such as sheep and goats. Foods such as the forage cactus are important sources of water for these animals (ARAÚJO et al., 2010). This fodder is characterized by a high physiological adaptation to water scarcity, being rich in carbohydrates, ashes, $\mathrm{Ca}$, and $\mathrm{K}$, but has low levels of crude protein and fibers (ATTI et al., 2006).

Forage cactus as silage is still little used. However, it is an interesting option for producers in regions facing water scarcity problems. Due to its richness in water, its storage as silage guarantee food and water for ruminants during critical periods of the year. This fodder can be used together with other forages richer in dry matter and protein, improving its nutritional value (ÇUREK; OZEN, 2004).

The study of ingestive behavior of animals has a great importance in the assessment of how diets are used since it allows adjustments in the feeding management in order to obtain better productive performances (MENDONÇA et al., 2004). However, studies assessing the effects of the use of forage cactus silage and intermittent water supply on the ingestive behavior of ruminants are still scarce in the literature.

In adverse weather conditions, regulation of consumption and loss of water is important for the maintenance of homeothermy in animals, allowing the resistance to the arid conditions by selecting milder conditions that mitigate stress in animals (OLIVEIRA et al., 2012). In this sense, the use of water-rich foods, such as forage cactus silage, may also be useful to ensure animal thermoregulation. The assessment of intermittent water supply on the thermoregulation process is also important, considering the need for water for this process.

Thus, this study aimed to assess the effect of using forage cactus silage on the ingestive behavior and thermoregulation of sheep submitted to an intermittent water supply.

\section{Material and Methods}

The experiment was carried out in the animal nutrition sector of EMBRAPA Semi-Arid (Brazilian Agricultural Research Corporation) located in Petrolina, PE, Brazil, between May and July 2015. Regional climate is Bsh'w according to Köppen's classification, with an average annual precipitation of $503 \mathrm{~mm}$ and an average maximum and minimum annual temperatures of 32.22 and $20.90{ }^{\circ} \mathrm{C}$, respectively (EMBRAPA, 2015).

We used thirty-six intact sheep of undefined genotype with an initial average weight of $19.8 \pm$ $2.1 \mathrm{~kg}$, previously weighed, dewormed to control parasites, and vaccinated against clostridiosis. These animals received vitamin and mineral supplementation via oral and were identified and randomly distributed in the treatments. They were confined in individual stalls with dimensions of $1 \times 2$ $\mathrm{m}$ with feeding and drinking troughs in an open shed.

The experimental design was a randomized block design in a $3 \times 3$ factorial scheme composed of three levels of forage cactus silage in the diet $(0,21$, and $42 \%$ based on DM $)$, three water supply periods $(0,24$, and 48 hours $)$, and four replications. The total experimental period of confinement was 84 days, with the first 10 days of adaptation to the management and diets.

Water was offered intermittently, according to the respective treatments. In the group of $0 \mathrm{~h}$, water was available ad libitum for the animals. In the group of $24 \mathrm{~h}$, water was available ad libitum for only 24 hours, being removed after this period and provided again after 24 hours so that the animals were left without water for 24 hours in the drinking trough. In the group of $48 \mathrm{~h}$, water was available for 24 hours, being removed after this period and provided again after 48 hours. Water was provided in plastic buckets and leftovers from the previous day were weighed daily. Water loss by evaporation was obtained by placing buckets with water distributed throughout the shed and weighing them the next day to record the amount of water that was evaporated. 
Diets were formulated according to NRC (2007) for a weight gain of $150 \mathrm{~g} \mathrm{day}^{-1}$ and were composed basically of hay of Tifton grass, which was partially replaced by forage cactus silage and concentrated ration based on corn bran, soybean meal, wheat bran, and mineral salt. The forage to concentrate ratio was 60:40 and the forage cactus silage (Opuntia fícusindica Mill) was used replacing the forage according to the treatments. Diets were provided twice a day at 9:00 and 15:00 h. Food leftovers were weighed daily for intake determination. The amount of food offered was calculated based on the consumption of the previous day, always considering leftovers of $10 \%$. Samples from the offered diets and leftovers were sent to the laboratory for performing bromatological analyses.

The forage cactus used in the experiment was obtained in a cactus plantation with more than 4 years of age of a single producer from Senhor do Bonfim,
BA, Brazil. The plant was cut and transported to EMBRAPA Semi-Arid, being subsequently processed in a forage harvester and stored in 200L plastic barrels and 1000-L water tanks. After all the material was compacted, the silo was sealed in order to avoid the oxygen entry, thus guaranteeing the anaerobic fermentation. These silos remained closed for at least 30 days, after which they were opened and the silage was used to feed the animals as needed.

Air temperature, relative humidity, black globe temperature (BGT), and dew point temperature (DPT) were recorded by using black globe thermometers coupled to data-loggers in the animals' confinement environment (Table 1). The black globe temperature humidity index (BGHI) was calculated from the environmental data as the following equation: $\mathrm{BGHI}=\mathrm{BGT}+0.36 \times \mathrm{DPT}+$ 41.5 (BUFFINGTON et al., 1981).

Table 1. Air temperature (AT), black globe temperature (BGT), relative humidity (RH), and black globe temperature humidity index (BGHI) of the experimental environment at the time of measurement of physiological responses of sheep fed forage cactus silage and submitted to an intermittent water supply.

\begin{tabular}{ccccc}
\hline PERIOD & $\mathrm{AT}\left({ }^{\circ} \mathrm{C}\right)$ & $\mathrm{BGT}\left({ }^{\circ} \mathrm{C}\right)$ & $\mathrm{RH}$ & BGHI \\
\hline $7: 00$ & 23.2 & 23.4 & 79.2 & 71.8 \\
$15: 00$ & 30.9 & 30.9 & 44.9 & 78.7 \\
\hline
\end{tabular}

The chemical composition of diet ingredients (Table 2), leftovers, and diets were analyzed for determining dry matter (DM), organic matter $(\mathrm{OM})$, mineral matter (MM), ethereal extract (EE), cellulose (CEL), lignin (LIG), and hemicellulose (HEM) according to the methodology described by AOAC (2000), crude protein (CP) by the Kjeldahl method, and NDF and ADF according to the methodology of Van Soest et al. (1991), with NDF corrected for ash and protein (NDFap) according to methodology proposed by Licitra et al. (1996) and Mertens (2002).

For the estimation of total carbohydrates (TC), we used the equation proposed by Sniffen et al. (1992): TC $=100-(\% \mathrm{CP}+\% \mathrm{EE}+\% \mathrm{ASH})$. For calculating the non-fibrous carbohydrates (NFC), we used the equation recommended by Hall et al. (1999): NFC $=\% \mathrm{TC}-\% \mathrm{NDFap}$.

In order to determine the ingestive behavior, the instantaneous scanning method, proposed by Martin and Bateson (1986), was adopted and the time spent in feeding, ruminating, and idling was recorded. For this, visual observation of animals was registered every 5 minutes for 2 periods of 24 hours each, performed on the $33 \mathrm{rd}$ and 62 nd days of confinement and taking the average of both. Observations were carried out in a relay system by observers previously trained, positioned strategically to avoid changes in animal routine. 
Feeding and rumination efficiencies and the total chewing time were obtained by the equations Efe = $\mathrm{DMI} / \mathrm{FT}, \mathrm{Eru}=\mathrm{DMI} / \mathrm{RT}$, and TCT $=\mathrm{FT}+\mathrm{RT}$, where Efe is the feeding efficiency $\left(\mathrm{g} \mathrm{DM} \mathrm{h}^{-1}\right)$, DMI is the dry matter intake $\left(\mathrm{g} \mathrm{DM} \mathrm{day}^{-1}\right)$, FT is the feeding time $\left(\mathrm{h} \mathrm{day}^{-1}\right)$, Eru is the rumination efficiency $(\mathrm{g}$ $\mathrm{DM} \mathrm{h}^{-1}$ ), RT is the rumination time $\left(\mathrm{h} \mathrm{day}^{-1}\right)$, TCT is the total daily chewing time $\left(\mathrm{h} \mathrm{day}^{-1}\right)$.

Table 2. Participation of ingredients and chemical composition of experimental diets.

\begin{tabular}{lccc}
\hline \multirow{2}{*}{ Ingredient $\left(\mathrm{g} \mathrm{DM} \mathrm{kg}^{-1}\right)$} & \multicolumn{3}{c}{ Levels of forage cactus silage } \\
\cline { 2 - 4 } Corn bran & $0 \%$ & $21 \%$ & $42 \%$ \\
Soybean meal & 280.00 & 230.00 & 180.00 \\
Wheat Bran & 80.00 & 100.00 & 120.00 \\
Tifton hay & 30.00 & 60.00 & 90.00 \\
Forage cactus silage & 600.00 & 390.00 & 180.00 \\
Mineral salt & 0.00 & 210.00 & 420.00 \\
\hline & 10.00 & 10.00 & 10.00 \\
\hline DM & Chemical composition $\left(\mathrm{g} \mathrm{DM}^{-1}\right)^{1}$ & 541.70 \\
OM & 883.20 & 712.40 & 892.10 \\
CP & 940.70 & 916.40 & 145.10 \\
EE & 111.00 & 128.10 & 25.40 \\
NDFap & 24.50 & 25.00 & 423.70 \\
ADF & 506.80 & 465.30 & 222.70 \\
TC & 265.80 & 244.30 & 720.40 \\
NFC & 804.10 & 762.20 & 296.60 \\
CEL & 297.20 & 296.90 & 182.50 \\
HEM & 223.90 & 203.20 & 201.00 \\
LIG & 241.00 & 221.00 & 4.02 \\
MM & 4.19 & 4.10 & 107.90 \\
\hline
\end{tabular}

${ }^{1}$ Dry matter (DM), organic matter (OM), mineral matter (MM), ethereal extract (EE), crude protein (CP), neutral detergent fiber corrected for ash and protein (NDFap), acid detergent fiber (ADF), total carbohydrates (TC), non-fibrous carbohydrates (NFC), cellulose (CEL), hemicellulose (HEM), and lignin (LIG).

${ }^{2}$ Based on the natural matter.

The physiological variables search for water, urinary frequency, and defecation frequency were observed on the same days of the ingestive behavior, continuously, by registering the number of times the animal searched for water, urinated, or defecated within 24 hours.

Thermoregulatory responses of animals were recorded at 7:00 and 15:00 $\mathrm{h}$ during four nonconsecutive days. The variables respiratory rate (RR), heart rate (HR), rectal temperature (RT), and surface temperature (ST) were measured.
Respiratory and heart rates were measured by counting respiratory movements per minute using a flexible stethoscope placed at the level of the thoracic region. The number of respiratory movements was taken in 15 seconds and then multiplied by 4 , thus obtaining the number of movements per minute.

Rectal temperature (RT) was obtained by using a digital clinical thermometer with a scale of 32 to $43.9^{\circ} \mathrm{C}$, which was inserted into the animal's rectum so that the bulb was in contact with the mucosa, remaining there for a period until a sound 
signal indicating the temperature stabilization.

The surface temperature was obtained by means of a FLUKE infrared thermometer model 66/68, which allows scanning the place and provides the average temperature of the point indicated by the laser emitted by the thermometer. The points covered were forehead, neck, rack, loin, thigh, cannon, and belly. The average surface temperature was obtained at an average distance of $20 \mathrm{~cm}$ from the animal.

The data were submitted to the analysis of variance (Proc GLM) by using the Statistical Analysis System (SAS INSTITUTE, 2002) and the Tukey's test at 5\% probability level was applied for mean comparison between treatments.

\section{Results and Discussion}

No interaction was observed between the levels of forage cactus silage and intermittent water supply. No significant effect was observed for intermittent water supply on the studied variables. The use of forage cactus silage in the diet, however, influenced both the ingestive behavior and thermoregulation of animals.

Dry matter intake (DMI) was significantly higher in animals fed diets with forage cactus silage (Table 3), with no differences between the levels of 21 and $42 \%$, with averages of 657.22 and 817.28 g DM day ${ }^{-1}$ in animals fed control diet and forage cactus silage ( 21 or $42 \%)$, respectively.

Table 3. Ingestive behavior of sheep fed forage cactus silage and submitted to an intermittent water supply.

\begin{tabular}{lcccccccccc}
\hline \multirow{2}{*}{ Item } & \multicolumn{3}{c}{ Levels of forage cactus silage (\%) } & \multicolumn{3}{c}{ Intermittent water supply (h) } & SE & \multicolumn{4}{c}{ p-value } \\
\cline { 2 - 12 } & 0 & 21 & 42 & 0 & 24 & 48 & & $\mathrm{~S}$ & $\mathrm{~W}$ & $\mathrm{~S} \times \mathrm{W}$ \\
\hline DMI (g) & $657.22 \mathrm{~b}$ & $795.11 \mathrm{a}$ & $839.46 \mathrm{a}$ & 791.55 & 724.77 & 775.47 & 25.51 & 0.0020 & 0.3310 & 0.9680 \\
iNDF (g) & 308.09 & 319.18 & 344.51 & 334.14 & 314.28 & 323.37 & 9.85 & 0.2160 & 0.6340 & 0.9560 \\
FT (min) & 205.83 & 189.17 & 200.21 & 200.00 & 204.58 & 190.63 & 6.39 & 0.4314 & 0.5915 & 0.1948 \\
RT (min) & 511.75 & 518.25 & 489.17 & 535.56 & 492.00 & 496.25 & 7.34 & 0.2337 & 0.0813 & 0.4161 \\
IT (min) & 746.88 & 705.00 & 753.54 & 713.75 & 744.17 & 765.00 & 10.73 & 0.1365 & 0.4465 & 0.4957 \\
TCT (min) & 716.00 & 704.75 & 688.89 & 720.28 & 698.00 & 694.50 & 9.26 & 0.4284 & 0.4795 & 0.4123 \\
Efe $\left(\mathrm{g} \mathrm{DM} \mathrm{h}^{-1}\right.$ ) & $198.63 \mathrm{~b}$ & $266.12 \mathrm{a}$ & $245.43 \mathrm{a}$ & 253.81 & 222.37 & 232.72 & 7.84 & $<.0001$ & 0.3953 & 0.5390 \\
Eru $\left(\mathrm{g} \mathrm{DM} \mathrm{h} \mathrm{h}^{-1}\right.$ ) & $78.456 \mathrm{c}$ & $91.78 \mathrm{~b}$ & $112.55 \mathrm{a}$ & 92.23 & 89.91 & 99.35 & 3.13 & $<.0001$ & 0.1490 & 0.9400 \\
\hline
\end{tabular}

Means followed by different letters in the row differ from each other by the Tukey's test at 5\% probability level.

Dry matter intake (DMI), NDF intake (iNDF), time spent in ruminating (RT), time spent in feeding (FT), time spent in idling (IT), total daily chewing time (TCT), feeding efficiency (Efe), rumination efficiency (Eru), standard error of the mean (SE), silage (S), intermittent water supply $(\mathrm{W})$, and interaction between silage and intermittent water supply $(\mathrm{S} \times \mathrm{W})$.

Forage cactus is a food that presents good acceptability by ruminants, leading to an increase of intake of diets that has this fodder in its composition (ALMEIDA, 2012). This fact may have been one of the main factors responsible for the increase in DM intake of animals that received this silage. Another factor that may have contributed was the lower NDF content in diets with forage cactus silage since, according to Mertens (1987), diets with a higher amount of fiber could have their intake reduced due to the physical capacity of ingestion. Costa et al. (2012) and Andrade et al. (2016) also observed an increase in DM intake when using in natura forage cactus in sheep diet.

The use of forage cactus silage in the diet did not affect neutral detergent fiber intake (iNDF). Despite the lower content of this nutrient observed in the forage cactus in relation to the Tifton hay, the higher intake of dry matter observed in the animals that received the forage cactus silage compensated this 
difference, matching the NDF intakes. Moreover, no effect of forage cactus silage in the diet was observed on feeding, rumination, idling, and total chewing times $(\mathrm{P}>0.05)$, possibly due to similar NDF intakes.

According to Van Soest (1994), the time spent in ruminating is determined by diet composition and it is proportional to the amount of cell wall in the forage, and the time spent with this activity may vary from 4 to 9 hours day $^{-1}$, although most common is that it lasts about 8 hours day ${ }^{-1}$. Thus, in this study, all levels of forage cactus silage and intermittent water supply provided an adequate rumination time.

Feeding efficiency (Efe) was significantly higher in animals fed forage cactus silage when compared to those that did not receive this food $(0 \%)$. Sheep fed control diet presented a feeding efficiency of $198.63 \mathrm{~g} \mathrm{DM} \mathrm{h}^{-1}$, while those fed diets with forage cactus silage presented an average feeding efficiency of $255.77 \mathrm{~g} \mathrm{DM} \mathrm{h}^{-1}$. This higher efficiency observed in animals fed forage cactus silage is probably due to the absence of differences in feeding time between treatments and the higher dry matter intake observed in animals fed this silage, allowing them to consume more food per unit of time. This result is in accordance with that observed by Bispo et al. (2010), who observed an increase in feeding efficiency when using forage cactus replacing elephant grass hay in sheep diet.

Rumination efficiency (Eru) was also higher in animals fed forage cactus silage. Eru provided by diets with 21 and $42 \%$ of this silage was 13.13 and $34.10 \mathrm{~g} \mathrm{DM} \mathrm{h}^{-1}$ higher than the efficiency observed in sheep fed control diet $(0 \%)$, respectively. This result may be attributed to the higher dry matter intake of these animals, with a similar rumination time. Conceição et al. (2016) also observed higher rumination efficiency in sheep fed forage cactus in the diet.

The search for water by animals fed $42 \%$ forage cactus silage (Table 4) was lower than in those that did not receive this silage $(\mathrm{P}<0.05)$. Due to the high amount of water in forage cactus, the animals that fed this silage had part of their water needs already met, reducing the search for water in the drinking troughs. Bispo et al. (2010), Barbosa et al. (2012), and Costa et al. (2012) also observed similar results.

The use of forage cactus silage in the diet also increased urinary frequency in the animals $(\mathrm{P}<0.05)$. The number of times the animals urinated increased as the levels of forage cactus silage increased in the diet. The daily urinary frequency observed with the use of 21 and $42 \%$ of forage cactus silage (14.44 and 23.60 times day $^{-1}$ ) corresponded to 0.60 and 0.98 urination per hour, respectively, whereas animals fed control diet presented a value of 0.45 urination per hour. This behavior is certainly due to the high water content in the forage cactus silage. Thus, the animals fed this silage (21 and 42\%) ingested much more water $(2.5$ and $3.81 \mathrm{~kg}$ ) than those fed control diet $(1.4 \mathrm{~kg})$, leading to a higher urinary frequency. Barbosa et al. (2012) worked with forage cactus and urea in the diet of goats and observed a higher number of urination in animals fed higher levels of forage cactus in the diet.

At 15:00 h, when BGHI was higher (78.7), respiratory rate (RR) was affected by the levels of forage cactus silage in the diet. Animals fed this diets presented higher RR values, with no difference between the levels used ( 21 or $42 \%$ ). One of the hypotheses for this behavior may be their higher dry matter intake observed. According to Baccari Júnior (2001), endogenous heat production in ruminants is influenced by food intake and may vary both as a function of quantity and quality of the ingested food. Because the heat gain also increased due to the higher BGHI observed at that time, the excess heat was dissipated through the increase of RR.

The levels of forage cactus silage in the diet influenced significantly sheep thermoregulation (Table 5), except for surface temperature, which presented no significant differences between treatments $(\mathrm{P}>0.05)$. 
Table 4. Average of the physiological variables search for water, urine, and feces of sheep fed diets with forage cactus silage and submitted to an intermittent water supply.

\begin{tabular}{lcccccccccc}
\hline \multirow{2}{*}{$\begin{array}{c}\text { Item } \\
\text { (no. day }^{-1} \text { ) }\end{array}$} & \multicolumn{4}{c}{ Levels of forage cactus silage (\%) } & \multicolumn{3}{c}{ Intermittent water supply (h) } & SE & \multicolumn{3}{c}{ p-value } \\
\cline { 2 - 11 } & 0 & 21 & 42 & 0 & 24 & 48 & & $\mathrm{~S}$ & $\mathrm{~W}$ & $\mathrm{~S} \times \mathrm{W}$ \\
\hline SW & $2.73 \mathrm{a}$ & $1.85 \mathrm{ab}$ & $0.54 \mathrm{~b}$ & 1.80 & 1.60 & 1.70 & 1.24 & 0.0014 & 0.6468 & 0.0670 \\
URINE & $10.83 \mathrm{c}$ & $14.44 \mathrm{~b}$ & $23.60 \mathrm{a}$ & 18.17 & 16.04 & 15.75 & 2.41 & 0.0001 & 0.2560 & 0.1220 \\
FECES & 15.92 & 13.78 & 13.45 & 14.91 & 14.25 & 14.30 & 3.33 & 0.1865 & 0.8283 & 0.1033 \\
\hline
\end{tabular}

Means followed by different letters in the row differ from each other by the Tukey's test at $5 \%$ probability level.

Standard error of the mean (SE), search for water (SW), silage (S), intermittent water supply (W), and interaction between silage and intermittent water supply $(\mathrm{S} \times \mathrm{W})$.

Table 5. Thermoregulatory responses of sheep fed diets with forage cactus silage submitted to an intermittent water supply.

\begin{tabular}{|c|c|c|c|c|c|c|c|c|c|c|}
\hline \multirow[t]{2}{*}{ Item } & \multicolumn{3}{|c|}{ Levels of forage cactus silage (\%) } & \multicolumn{3}{|c|}{ Intermittent water supply (h) } & \multirow[t]{2}{*}{ SE } & \multicolumn{3}{|c|}{ p-value } \\
\hline & 0 & 21 & 42 & 0 & 24 & 48 & & $\mathrm{~S}$ & $\mathrm{~W}$ & $\mathrm{~S} \times \mathrm{W}$ \\
\hline Time & \multicolumn{10}{|c|}{$7: 00 \mathrm{~h}$} \\
\hline RR (mov. min $^{-1}$ ) & 50.91 & 62.41 & 56.72 & 54.33 & 55.18 & 60.42 & 2.65 & 0.1702 & 0.5427 & 0.2618 \\
\hline HR (mov. $\min ^{-1}$ ) & $97.75 b$ & 107. $5 \mathrm{ab}$ & $115.42 \mathrm{a}$ & 103.67 & 104.08 & 112.92 & 2.47 & 0.0123 & 0.1788 & 0.5372 \\
\hline $\mathrm{RT}\left({ }^{\circ} \mathrm{C}\right)$ & $38.32 b$ & $38.65 \mathrm{ab}$ & $38.75 \mathrm{a}$ & 38.58 & 38.52 & 38.63 & 0.06 & 0.0123 & 0.7566 & 0.9684 \\
\hline $\mathrm{ST}\left({ }^{\circ} \mathrm{C}\right)$ & 28.35 & 27.93 & 28.00 & 28.19 & 28.24 & 27.85 & 0.15 & 0.5577 & 0.5842 & 0.9958 \\
\hline Time & \multicolumn{10}{|c|}{$15: 00 \mathrm{~h}$} \\
\hline RR (mov. min $^{-1}$ ) & $76.08 \mathrm{~b}$ & $105.91 \mathrm{a}$ & $100.36 \mathrm{a}$ & 95.66 & 90.36 & 95.50 & 4.28 & 0.0063 & 0.8746 & 0.3056 \\
\hline HR (mov. $\min ^{-1}$ ) & $111.08 \mathrm{~b}$ & $137.5 \mathrm{a}$ & $142.67 \mathrm{a}$ & 129.33 & 132.67 & 129.25 & 2.98 & $<.0001$ & 0.6869 & 0.3272 \\
\hline $\mathrm{RT}\left({ }^{\circ} \mathrm{C}\right)$ & $39.33 b$ & $39.44 \mathrm{ab}$ & $39.55 \mathrm{a}$ & 39.43 & 39.45 & 39.45 & 0.03 & 0.0390 & 0.9523 & 0.8824 \\
\hline $\mathrm{ST}\left({ }^{\circ} \mathrm{C}\right)$ & 32.69 & 32.96 & 33.07 & 32.97 & 32.74 & 33.02 & 0.14 & 0.5289 & 0.6693 & 0.9673 \\
\hline
\end{tabular}

Means followed by different letters in the row differ from each other by the Tukey's test at 5\% probability level.

Respiratory rate (RR), heart rate (HR), rectal temperature (RT), surface temperature (ST), standard error of the mean (SE), silage $(\mathrm{S})$, intermittent water supply $(\mathrm{W})$, and interaction between silage and intermittent water supply $(\mathrm{S} \times \mathrm{W})$.

Silanikove (2000) stated that respiratory rates of 40-60, 60-80, and 80-120 mov. $\mathrm{min}^{-1}$ characterize, respectively, low, medium-high, and high stress for ruminants. At 15:00 h, animals fed forage cactus silage ( 21 or $42 \%$ ) presented, on average, a respiratory rate of $103.13 \mathrm{mov}$. $\mathrm{min}^{-1}$. Thus, at that time, animals that fed these diets would be under a high stress (80-120 mov. $\mathrm{min}^{-1}$ ). However, because there was a reduction in the search for water and an increase in DM intake, possibly these animals did not suffer stress due to their adaptability (undefined genotype) to the warm climate of this semi-arid region.
Heart rate (HR) of animals was affected by diets with forage cactus silage at both assessed periods ( $\mathrm{P}$ $<0.05$ ). At 7:00, when BGHI was 71.8, animals fed $42 \%$ forage cactus silage presented a higher heart rate (111.42 mov. $\left.\mathrm{min}^{-1}\right)$ when compared to those fed control diet $\left(97.75\right.$ mov. $\left.\mathrm{min}^{-1}\right)$. On the other hand, at 15:00 h, when BGHI was 78.7, animal behavior was similar to that found for RR. Both levels of forage cactus silage used increased this variable.

An increased heart rate is another form of heat dissipation. In addition, an increase in heart rate increases blood flow to the skin, i.e. it transfers 
heat from the inside the body to the skin. Probably, this variable increased for the same reasons as RR increased, i.e. to dissipate excess heat from animals' body, thus guaranteeing its homeothermy. The results observed in our study are in accordance with those observed by Macome et al. (2012), who observed that sheep that consumed more food had a higher HR.

The observed heart rate values are above those reported as normal by Reece (1996), which should be between 70 and 80 mov. $\mathrm{min}^{-1}$ in goats and sheep under idling state. However, Detweiler (1988) pointed out that the data found for HR in the literature generally vary due to different environmental conditions in which they were obtained.

For rectal temperature (RT), differences were observed at both periods only between treatments of 0 and $42 \%$ forage cactus silage, the latter leading to a higher rectal temperature. However, because the increase in RT was minimal, the excess heat was efficiently dissipated by means of thermoregulatory mechanisms, evidenced by an increase in respiratory and heart frequencies.

According to Pereira et al. (2011), RT is considered the physiological reference variable for assessing animal homeothermy. Despite the increased rectal temperature observed in our study, its values were similar to those reported as normal by Swenson (1988), which is $39.1^{\circ} \mathrm{C}$.

\section{Conclusions}

Forage cactus silage, when used in sheep diet in the levels of 21 and $42 \%$ of dry matter, increases feeding and rumination efficiencies, in addition to reducing the search for water. However, it also increases animal thermoregulatory responses, without an indication of severe stress. The intermittent water supply in periods of 24 and 48 hours does not influence the ingestive behavior and thermoregulation of confined sheep under thermal comfort.

\section{References}

ABDELATIF, A. M.; ELSAYED, S. A.; HASSAN, Y. M. Effect of state of hydration on body weight, blood constituents and urine excretion in nubian goats (Capra hircus). World Journal of Agricultural Sciences, Albany, v. 6, n. 2, p. 178-188, 2010.

ADOGLA-BESSA, T.; AGANGA, A. A. Responses of Tswana goats to various lengths of water deprivation. South African Journal of Animal Science, Legon, v. 30, n. 1, p. 87-91, 2000.

ALAMER, M. Effect of water restriction on lactation performance of Aardi goats under heat stress conditions. Small Ruminant Research, v. 84, n. 1, p. 76-81, 2009.

ALMEIDA, R. F. Palma forrageira na alimentação de ovinos e caprinos no Semiárido Brasileiro. Revista Verde de Agroecologia e Desenvolvimento Sustentável, Mossoró, v. 7, n. 4, p. 8-14, 2012.

AL-RAMAMNEH, D.; RIEK, A.; GERKEN, M. Effect of water restriction on drinking behaviour and water intake in German black-head mutton sheep and Boer goats. Animal, Cambridge, v. 6, n. 1, p. 173-178, 2011.

ANDRADE, S. F. J.; BATISTA, A. M. V.; CARVALHO, F. F. R.; LUCENA, R. B.; ANDRADE, R. P. X.; LIMA JUNIOR, D. M. Fresh or dehydrated spineless cactus in diets for lambs. Acta Scientiarum Animal Science, Maringá, v. 38, n. 2, p. 155-161, 2016.

ARAÚJO, G. G. L.; VOLTOLINI, T. V.; CHIZZOTTI, M. L.; TURCO, S. H. N.; CARVALHO, F. F. R. Water and small ruminant production. Revista Brasileira de Zootecnia, Viçosa, MG, v. 39, p. 326-336, 2010. Suplemento Especial.

ASSOCIATION OF OFFICIAL ANALYTICAL CHEMISTS - AOAC. Official methods of analysis of AOAC International. $19^{\text {th }}$ ed. Washington: AOC International, 2000. $1219 \mathrm{p}$.

ATTI, N.; MAHOUACHI, M.; ROUISSI, H. The effect of spineless cactus (Opuntia ficus-indica f. inermis) supplementation on growth, carcass, meat quality and fatty acid composition of male goat kids. Meat Science, Savoy, v. 73, n.1, p. 229-235, 2006.

BACCARI JÚNIOR, F. Manejo ambiental da vaca leiteira em climas quentes. Londrina: Universidade Estadual de Londrina, 2001. 142 p.

BARbosa, J. G.; COSTA, R. G.; MEdEIROS, A. N.; QUEIROGA, R. C. R. E.; BATISTA, A. M. V.; MEDEIROS, G. R.; BELTRÃO FILHO, E. M. Use of different urea levels in the feeding of Alpine goat. Revista Brasileira de Zootecnia, Viçosa, MG, v. 41, n. 7, p. 17131719, 2012. 
BISPO, S. V.; FERREIRA, M. A.; VÉRAS, A. S. C.; MODESTO, E. C.; GUIMARÃES, A. V.; PESSOA, R. A. S. Comportamento ingestivo de vacas em lactação e de ovinos alimentados com dietas contendo palma forrageira. Revista Brasileira de Zootecnia, Viçosa, MG, v. 39, n. 9, p. 2024-2031, 2010.

BUFFINGTON, D. E.; COLLAZOAROCHO, A.; CANTON, G. H.; PITT, D. Black globe-humidity index (BGHI) as comfort equation for dairy cows. Transactions of the ASAE, Saint Joseph, v. 24, n. 3, p. 711-714, 1981.

CASAMASSIMA, D.; PIZZO, R.; PALAZZO, M.; D'ALESSANDRO, A. G.; MARTEMUCCI, G. Effect of water restriction on productive performance and blood parameters in comisana sheep reared under intensive condition. Small Ruminant Research, v. 78, n.1, p. 169175, 2008.

CONCEIÇÃO, M. G.; FERREIRA, M. A.; CAMPOS, J. M. S.; SILVA, J. L.; DETMANN, E.; SIQUEIRA, M. C. B.; BARROS, L. J. A.; COSTA, C. T. F. Replacement of wheat bran with spineless cactus in sugarcane-based diets for steers. Revista Brasileira de Zootecnia, Viçosa, MG, v. 45, n. 4, p. 158-164, 2016.

COSTA, R. G.; TREVIÑO, I. H.; MEDEIROS, G. R.; MEDEIROS, A. N.; PINTO, T. F.; OLIVEIRA, R. L. Effects of replacing corn with cactus pear (Opuntia ficus indica Mill) on the performance of Santa Inês lambs. Small Ruminant Research, v. 102, n.1, p. 13-17, 2012.

ÇUREK, M.; OZEN, N. Feed Value of cactus and cactus silage. Turkish Journal of Veterinary and Animal Science, v. 28, n.1, p. 633-639, 2004.

DETWEILER, D. R. Regulação cardíaca. In: DUKES, H. H.; SWENDSON, M. J. Fisiologia dos animais domésticos. 10. ed. Rio de Janeiro: Guanabara Koogan, 1988. p. 113-143.

EMPRESA BRASILEIRA DE PESQUISA AGROPECUÁRIA-EMBRAPA. Dados meteorológicos. Petrolina: EMBRAPA Semiárido, 2015. Disponível em: $\quad<$ http://www.cpatsa.embrapa.br:8080/servicos/ dadosmet/ceb-dia.html>. Acesso em: 29 jul. 2015.

HALL, M. B.; HOOVER, W. H.; JENNINGS, J. P.; WEBSTER, T. K. M. A method for partitioning neutral detergent soluble carbohydrates. Journal Science Food Agriculture, v. 79, n. 15, p. 2079-2086, 1999.

LICITRA, G.; HERNANDEZ, T. M.; VAN SOEST, P. J. Standardization of procedures for nitrogen fractionation of ruminant feeds. Animal Feed Science and Technology, v. 57, n. 4 , p. $347-358,1996$.

MACOME, F. M.; OLIVEIRA, R. L.; ARAÚJO, G. G. L.; BARBOSA, L. P.; CARVALHO, G. G. P.; GARCEZ
NETO, A. F.; SILVA, T. M. Respostas de ingestão e fisiologicas de cordeiros alimentados com torta de dendê (Elaeis guineensis). Archivos de Zootecnia, Córdoba, v. 61, n. 235, p. 335-342, 2012.

MARTIN, P.; BATESON, P. Measuring behavior: an introductory guide. $3^{\text {th }}$ ed. New York: Cambridge University Press, 1986. 200 p.

MENDONÇA, S. S.; CAMPOS, J. M. S.; VALADARES FILHO, S. C.; VALADARES, R. F. D.; SOARES, C. A.; LANA, R. P.; QUEIROZ, A. C.; ASSIS, A. J.; PEREIRA, M. L. A. Comportamento ingestivo de vacas leiteiras alimentadas com dietas à base de cana-de-açúcar ou silagem de milho. Revista Brasileira de Zootecnia, Viçosa, MG, v. 33, n. 3, p. 723-728, 2004.

MERTENS, D. R. Gravimetric determination of amylasetreated neutral detergent fiber in feeds with refluxing in beaker or crucibles: collaborative study. Journal of AOAC International, v. 85, n. 6, p. 1217-1240, 2002.

MERTENS, D. R. Predicting intake and digestibility using mathematical models of ruminal function. Journal of Animal Science, Champaign, v. 64, n.1, p. 1548-1558, 1987.

NATIONAL RESEARCH COUNCIL - NRC. Nutrient requirements of small ruminants: sheep, goats, cervids, and new world camelids. Washington: The National Academic Press, 2007. 384 p.

OLIVEIRA, P. T. L.; TURCO, S. H. N.; ARAÚJO, G. G. L.; VOLTOLINI, T. V.; MENEZES, D. R.; SILVA, T. G. F. Comportamento ingestivo e parâmetros fisiológicos de bovinos Sindi alimentados com teores crescentes de feno de erva-sal. Revista Brasileira de Ciências Agrárias, Recife, v. 7, n. 1, p. 180-188, 2012.

PEREIRA, G. M.; SOUZA, B. B.; SILVA, A. M. A.; ROBERTO, J. V. B.; SILVA, C. M. B. A. Avaliação do comportamento fisiológico de caprinos da raça Saanen no semiárido paraibano. Revista Verde de Agrotecnologia e Desenvolvimento Sustentável, Mossoró, v. 6, n.1, p. 8388, 2011.

REECE, W. O. Fisiologia de animais domésticos. São Paulo: Roca, 1996. 351 p.

SILANIKOVE, N. Effects of heat stress on the welfare of extensively managed domestic ruminants. Livestock Production Science, v. 67, n. 1, p. 1-18, 2000.

SILVA, C. M.; ARAÚJO, G. G. L.; OLIVEIRA, B. Y. S.; AZEVEDO, J. A. G.; FURTADO, D. A. Performance and economic viability of feedlot sheep fed different levels of roughage, concentrate, and water. Semina: Ciências Agrárias, Londrina, v. 37, n. 3, p. 1595-1606, 2016. 
SNIFFEN, C. J.; O'CONNOR, J. D.; VAN SOEST, P. J.; FOX, D. G.; RUSSELL, J. B. A net carbohydrate and protein system for evaluating cattle diets: II. Carbohydrate and protein availability. Journal of Animal Science, Champaign, v. 70, n. 11, p. 3562-3577, 1992.

STATISTICAL ANALYSIS SYSTEM INSTITUTE - SAS Institute. SAS/STAT user's guide. Cary: SAS Institute, 2002.
SWENSON, M. J. Duke's physiology of domestic animals. $10^{\text {th }}$ ed. Rio de Janeiro: Guanabara, 1988. 799 p.

VAN SOEST, P. J. Nutritional ecology of the ruminant. $2^{\text {th }}$ ed. London: Comstock Publishing Associates, 1994. $476 \mathrm{p}$.

VAN SOEST, P. J.; ROBERTSON, J. B.; LEWIS, B. A. Methods for dietary fiber, neutral detergent fiber, and nonstarch polysaccharides in relation to animal nutrition. Journal of Dairy Science, v. 74, n. 10, p. 3583-3597, 1991. 
